\title{
An Observational Study on Land and Sea Breezes in the Tokai Village Area
}

\author{
By Mitsuo Mizuma \\ Research Reactor Institute, Kyoto University, Kumatori, Osaka \\ and \\ Michio Kakuta \\ Japan Atomic Energy Research Institute, Tokai, Ibaraki \\ (Manuscript received 30 April 1974, in revised form 8 August 1974)
}

\begin{abstract}
Extensive observational programs on land and sea breezes were carried out by use of pibal method in the summer of 1971 and 1972 in the Tokai Village area facing the Pacific. Two pibal stations were set up at about one and six kilometers inland.

Significant results obtained are as follows:

(1) Vertical profiles of wind speed and direction in the lowest few hundred meters layer of the atmosphere in the sea breeze are significantly different between the coastal and the inland station, suggesting the effectiveness of the difference in surface friction over the land and the sea.

(2) Low level jet in the evening is observed in this area and its development is deeply connected with the existence of a surface inversion layer.

(3) The sea breeze observed is clearly of frontal type, which is about 400 meters thick in the vicinity of the front. The land breeze observed develops gradually from the ground surface upwards, under an opposing overriding flow.

Observations of wind and temperature over the sea with a research vessel and those of air trajectories by use of tetroons were carried out as a part of observational programs.
\end{abstract}

\section{Introduction.}

Land and sea breeze is a meteorological phenomenon to be easily recognized in the coastal region throughout the world. A large number of observational studies have been carried out to date, notable among which are those by Fisher (1960), Frizzola and Fisher (1963), Moroz (1967), Fraedrich (1968), Lyons (1970), Hsu (1970), and Johnson and O'Brien (1973), On the other hand, numerical simulation of land- and sea-breeze circulation has been undertaken by several authors (e.g., Estoque, 1960; Magata, 1965; Moroz, loc. cit.; McPherson, 1970; Neumann and Mahrer, 1972; Yoshikado and Asai, 1972) and has succeeded in reproducing the observed feature to a considerable extent. About 30 years ago, Wexler (1946) made a wide review on this subject from both observational and theroretical points of view and recently a detailed bibliography was published by Jehn (1973).

Nevertheless, it seems to the present authors that the existing observational results on land and sea breezes are not always accurate enough to be investigated in greater detail, because they are usually based on pibal observations of a single ascent at a particular time and consequently may leave some shortcomings in representing the average wind field at that time (e.g., Brooks, 1947). It seems, therefore, meaningful to undertake a new set of observations with some modifications on pibal observational method. An attempt was already reported by one of the authors (Mizuma, 1973), which is in accordance with a means adopted by Davidson (1963) for his observations on turbulence and wind variability.

In the Tokai Village, the present observational area, several nuclear reactors have been established for research and power-generating purposes. It is, therefore, necessary from the health-physical point 
of view that the behavior of land and sea breezes in this area is fully brought to light.

In the summer of 1971 and 1972, extensive observational programs on land and sea breezes were carried out in the Tokai Village area. The present paper describes the results of these observations.

\section{General Features of the Observational Area.}

The Tokai Village is located in a coastal region of Ibaraki Prefecture in the northern part of the Kanto Plain. The map of the observational area and its vicinity is shown in Fig. 1. The terrain

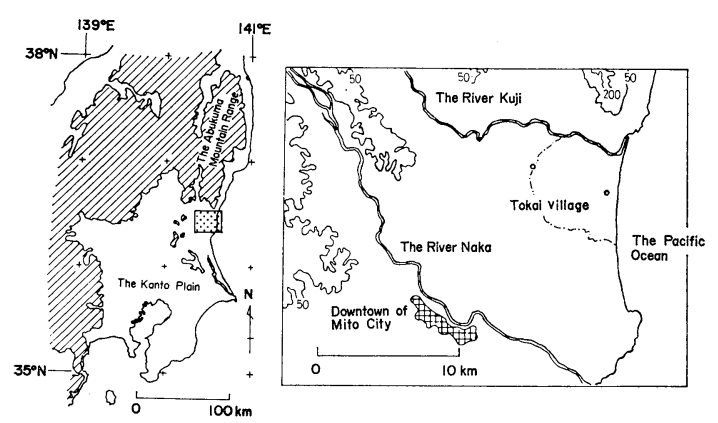

Fig. 1. Map of the observational area and its vicinity. Shadowed area in the left half shows the area higher than 200 meters above MSL. The right half shows magnified version of the dotted area in the left. Numeral in the right means height above MSL. Open circle shows the station.

is considerably flat for over 20 kilometers inland from the Pacific coast with a hilly region of the Abukuma Mountain Range about 6 kilometers to the north. The River kuji flows at the foot of this hilly region. The coastline running north and south is fairly straight for over 10 kilometers in the vicinity. The countryside is rural with small woods and bushes scattered among cultivated field. There are no large densely housed areas.

The Japan Atomic Energy Research Institute (JAERI) is situated at the coast. A highway runs NNE and SSW at about 6 kilometers inland, along which a few factories are established. JAERI has well-equipped meteorological facilities which provide climatological data on the area. The factories are also more or less installed with meteorological instruments which are available for additional observations.

In summary, it may be said that the area is one of the most favorable sites in our country for the observation of land and sea breezes without distortion owing to orographic conditions.

\section{Observational Programs and Instrumentations.}

Observations in the summer of 1971 were designed for obtaining typical wind profiles for both land and sea breezes. Winds aloft were measured using pibal method with doubletheodolite technique. For the purpose of obtaining representative profiles, several balloons were released successively during an about one hour run. Each ascent of a balloon with nominal rate of $130 \mathrm{~m} \cdot \mathrm{min}^{-1}$ was tracked at $20 \mathrm{sec}$ interval during an $8 \mathrm{~min}$ period. All profiles obtained are averaged for a mean profile. An example of the procedure is shown in Fig. 2. The mean profile obtained in this way is a good representation of the wind field during the run.

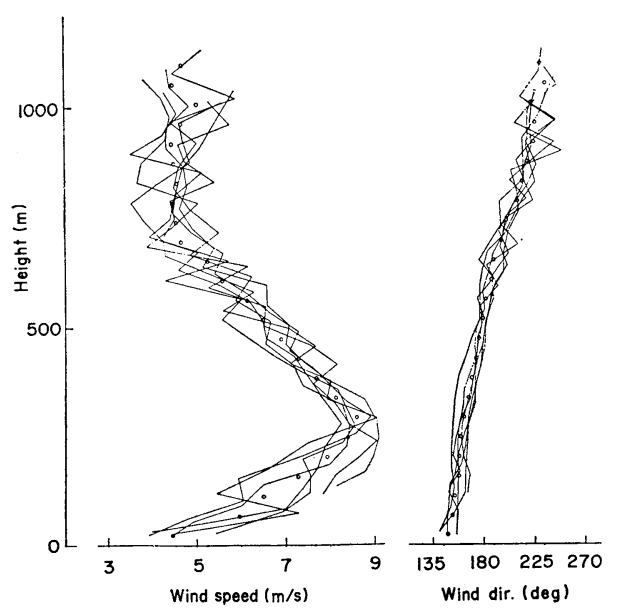

Fig. 2. An example of successive pilotballoon wind profiles. Open circle shows the average value.

Observations were done simultaneously at two stations. At the JAERI site, a pair of theodolites was placed with separation varied from 500 to 1000 meters case by case. Balloons were released at the meteorological tower about one kilometer inland from the coastline, which is hereinafter referred to as the coastal station. Another pair of theodolites was placed at the Mitsubishi Nuclear Fuel Co. and the Sumitomo Metal Mining Co., separation of instruments here was 1.1 kilometers. The ballon release point was at the former located about 6 kilometers inland, which is hereinafter referred to as the inland station. Two 
periods of around-the-clock observations were carried out. The first period began at 1500 JST 30 July and the second at 1100 JST 1 August. It takes more than an hour for a run to be completed because 7 balloons were usually released in a run. Therefore, an interval of 4 hours was taken between successive runs.

The 1972 observations were focussed on investigations of the changing process of wind during the passage of land- and sea-breeze front and air trajectories in the lower portion of landand sea-breeze circulation. The first set of observations was made on 28 to 29 July with release of balloons at 1.5 hours interval. Releases at shorter interval were to be made if necessary for obtaining the process in detail, but they were not tried during the observational period. Of course, this set of observations consists of pibal observation with a single ascent at a time and results obtained are not to be discussed concerning small wind variation owing to the reason discussed in $\S 1$. The arrangement of theodolites, balloon release points and method of tracking were the same as that for the 1971 observations. In fact, the 1971 observations provide good data for this problem if the changing process of wind occurs during a specific run. As is discussed later, we met with this case. The second set of observations was done on 30 to 31 July with releases of tetroons at 4 hours interval. The free lift of tetroons was adjusted to float on a level of 200 meters above the ground. The air temperature at this level necessary for the adjustment was measured with a type of radiosonde specially designed for the detailed measurement of air temperature within the first few thousand meters of the atmosphere, prior to the adjustment. However, we were often forced to rely upon a guess for the temperature on account of scarcity of measurements. The technique for raising a tetroon to flight altitude is similar to that described by Hass et al. (1967). The arrangement of theodolites and balloon release points were again the same as that for the previous studies, the tracking of a tetroon changed to a $30 \mathrm{sec}$ sampling interval during a period as long as tracking is made possible visually.

Continuous records of wind speed, direction and air temperature are desirable for the analysis. The meteorological tower at JAERI is about 40 meters high and continuous measurements are made at a few levels on the tower. Data are available for both years. In 1971, a propeller and vane wind sensor was available at the Sumitomo site and operated by us with a recording thermometer set up during the observational period. In 1972, continuous record of these elements were available at the Mitsubishi site. At both sites, wind sensors were installed on the top of the buildings at about 10 meters hight. Thermometers were set up at about 1.5 meters above the ground.

The sea water temperature is one of the controlling factors for the generation of land and sea breeze. In 1971, it was not measured after all during the observational period, but the measurement was done by Fisheries Experimental Station of Ibaraki Prefecture on 9 to 10 August, about a week after the observational period. In 1972, the sea water temperature was measured by a research vessel "Matsukaze" of JAERI together with wind speed, direction and air temperature at about 7 kilometers offshore during the first set of observations.

\section{Synoptic Situations for the Observational Periods.}

The synoptic situations for the 1971 observations are shown in Fig. 3. Included in the figure are winds and temperatures aloft at the Aerological Observatory at Tateno located about 60 kilometers distant to the southwest. A predominant north Pacific high covers the Japanese Islands. The wind at $850 \mathrm{mb}$ level, about 1500 meters height, is weak, suggesting the weakness of the winds appropriate to synoptic pressure gradient. Toward the end of the period, a severe typhoon was approaching the Japanese Islands, but it does not affect the observations. On the other hand, it was so warm even in the nighttime that the temperature difference between the land and the sea necessary for the generation of land breeze might not fully develop as is shown in Fig. 4. Although the sea water temperature shown here was measured at several points 10 to 30 kilometers offshore from the observational area about a week later, it is not expected that the sea water temperature changes greatly during a period of a week or so.

The synoptic situations for the 1972 observations are shown in Fig. 5. The situation for the first set (28 July) is not so simple; synoptic pressure pattern is a little complicated. Northeasterly wind accompanied by a ridge covering 

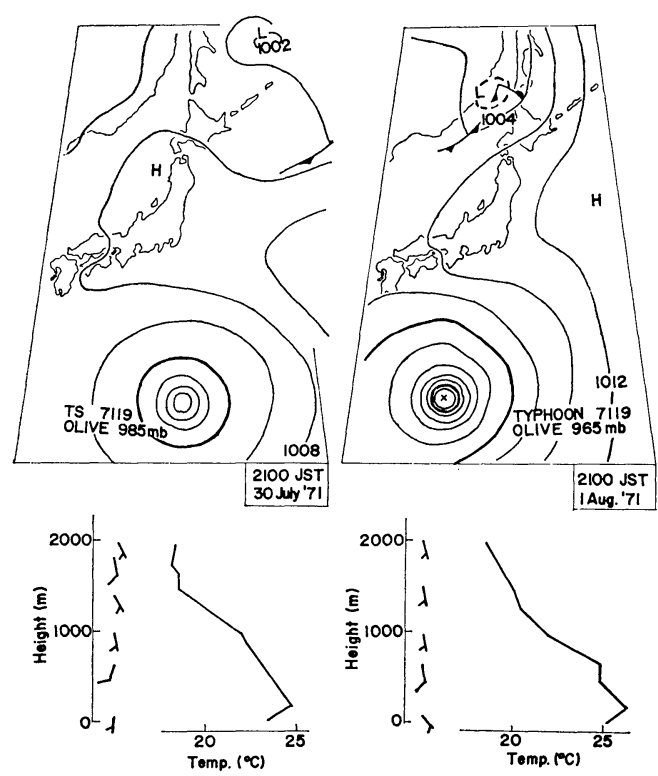

Fig. 3. Synoptic weather map and winds and temperatures aloft (1971). A barb indicates 10 knots, a half barb 5 knots. For details see the text.

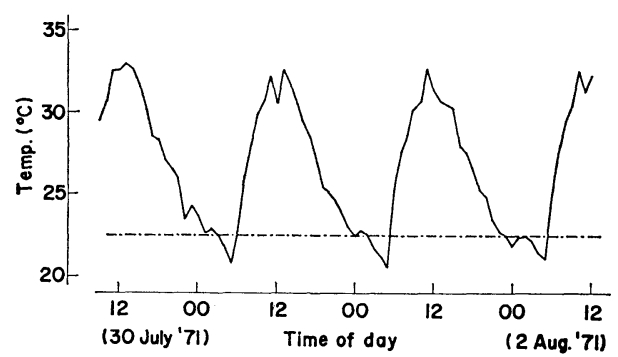

Fig. 4. Temperatures at the land and the sea (1971). Solid line shows air temperature at the inland station. Dash-dotted line shows sea water temperature, for details of which see the text.

the observational area prevails within the first several hundred meters layer of the atmosphere. However, according to the results of temperature measurements shown in Fig. 6, the temperature contrast between the land and the sea is quite favorable for the generation of land breeze for 28 July and that of sea breeze on the next day. The synoptic situation for the second set (30 July) is similar to that for the previous year. A heavy shower took place in the afternoon of 30 July and the observation had to be partly cancelled.
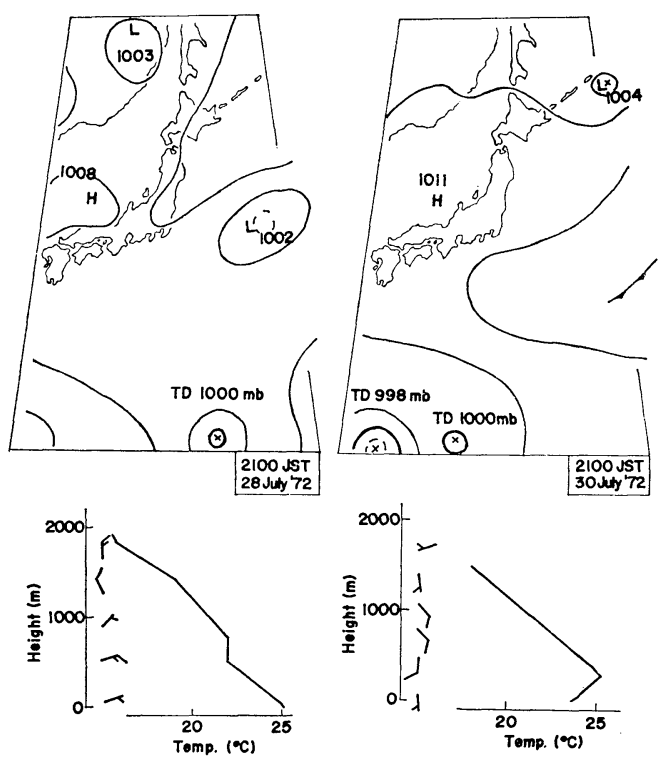

Fig. 5. Synoptic weather map and winds and temperatures aloft (1972). A barb indicates 10 knots. For details see the text.

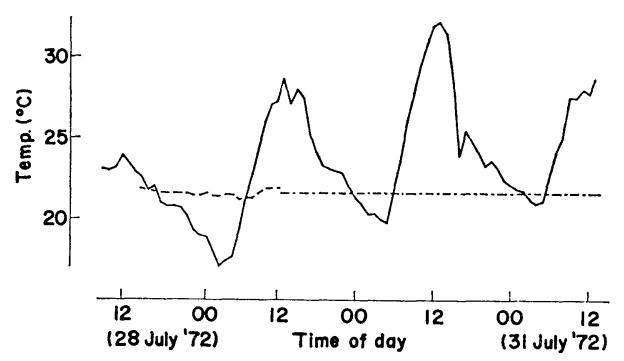

Fig. 6. Temperatures at the land and the sea (1972). Solid line shows air temperature at the inland station, dashed line sea water temperature 7 kilometers offshore, dash-dotted line its mean value.

\section{Observational Results and Discussion}

Well-defined sea breeze was observed during our three afternoon observations in 1971. Wind profiles are shown in Fig. 7. General features are not largely different from the known shape of wind profile in the sea breeze. It is evident from the figure that there are substantial differences between the coastal and the inland station in both wind speed and direction in the lowest few hundred meters above the ground surface. A significant maximum in wind speed appears at 


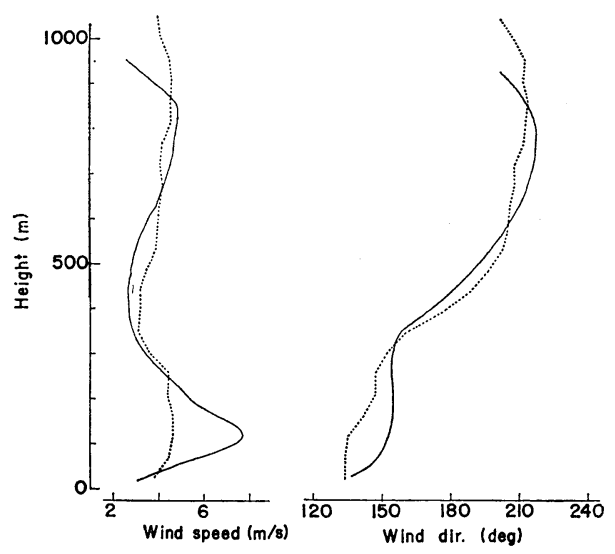

(a) $15 \mathrm{~h}, 30$ July 1971.

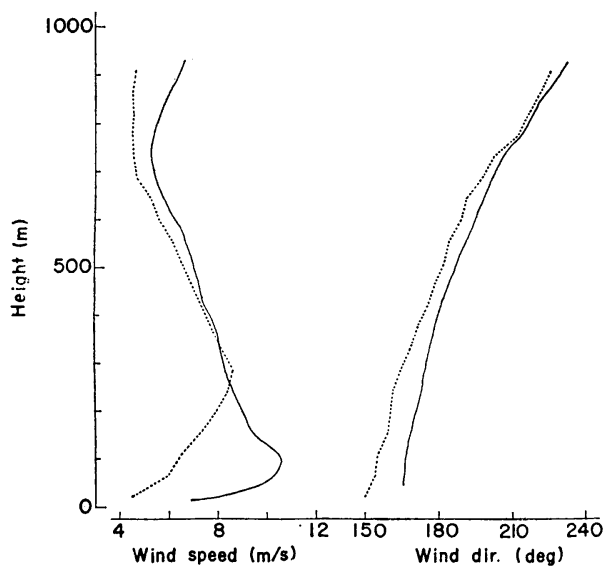

(b) 15 h, 31 July 1971.

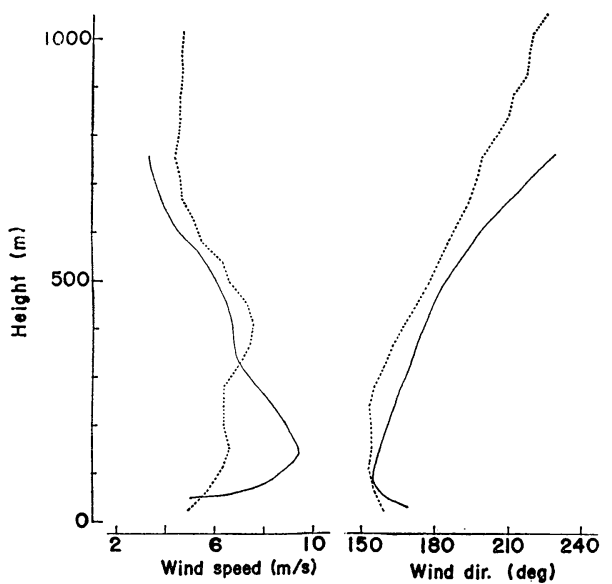

(c) $15 \mathrm{~h}, 1$ August 1971.

Fig. 7. Wind profiles for the sea breeze. Solid lines indicate those at the coastal station, dotted line the inland station. around 100 meters above the surface at the coastal station, but it is almost disappeared at the inland station. Wind direction within the first few hundred meters of the atmosphere backs by 10 to 20 degrees from the coastal to the inland station. It is obvious that wind blows parallel to the isobar under the geostrophic condition while perpendicular to it under the antitriptic one. The geostrophic condition is considered to correspond to negligible surface friction and the antitriptic one to predominant surface friction. Isobars are supposed to run parallel to the coastline under the sea-breeze situation. The above mentioned features may, therefore, suggest the effectiveness of the difference in surface friction between the sea and the land on the wind profile.

Furthermore, it is to be noted that in this location the wind directions are more parallel to the coastline than perpendicular to it. It has been widely observed (e.g., Estoque, loc. cit.) that a fully developed sea breeze has its direction only some tens of degrees apart from the normal to the coastline. The tendency here for wind direc-

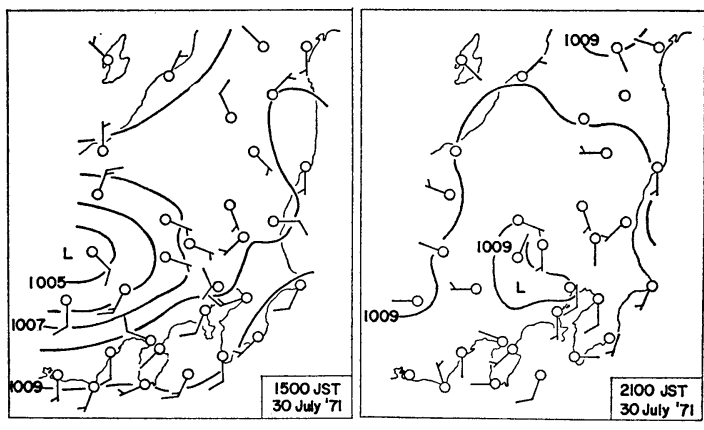

(a) 30 July.

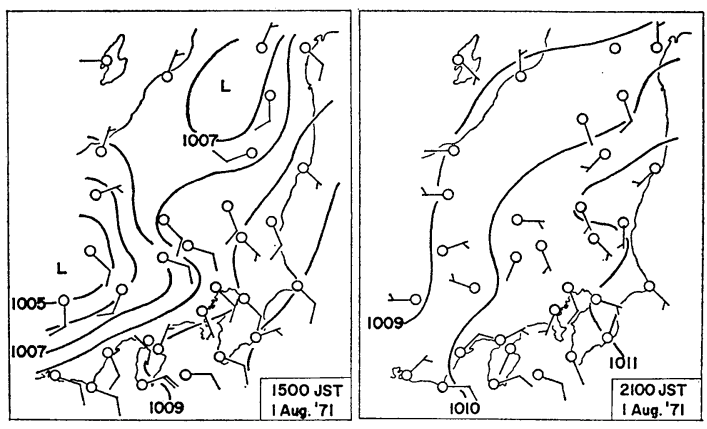

(b) 1 August.

Fig. 8. Local weather maps for Kanto district and its environs (1971). A barb indicates 10 knots, a half-barb 5 knots. 
tion to be rather parallel to the coastline for the fully developed sea breeze has also been confirmed by a statistical analysis of tower measurements of wind direction at JAERI (Imai, 1968). Local weather map for Kanto district and its environs are drawn for this feature to be studied, which are shown in Fig. 8. As can be seen from the figure, a well-defined depression is centered at a mountaineous region of central plateau district and covers the Kanto Plain in the daytime, which may be a thermal low. Wind directions seem affected by this depression to a considerable extent in the southeastern coast of Japan.

A tendency for wind speed to increase toward the evening in the lowest few hundred meters of the atmosphere is shown in Fig. 9, very clearly on 30 July 1971 (Fig. 9a) but not so significantly on 1 August 1971 (Fig. 9b). There is little difference in this feature between the coastal and

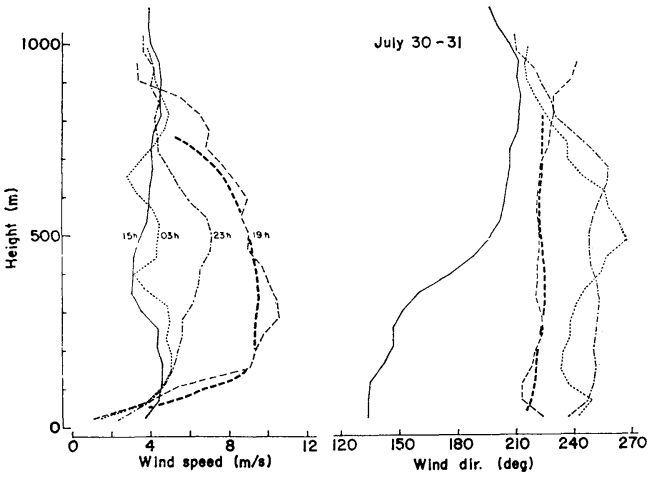

(a)

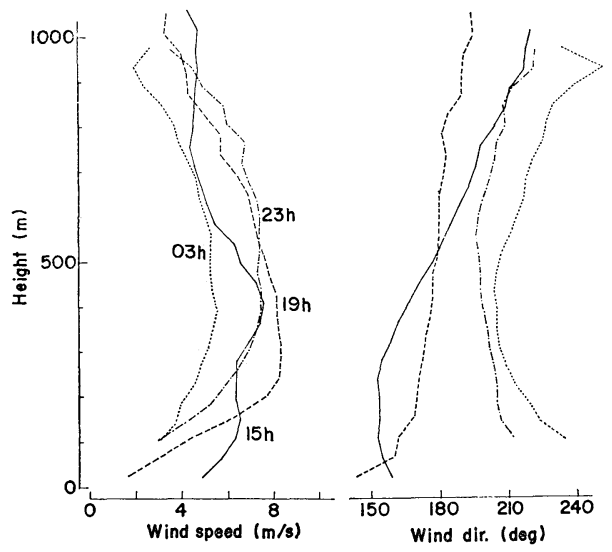

(b)

Fig. 9. Low level jet in the evening.

(a) 30-31 July 1971. Heavy dashed line shows wind profiles at the coastal station at $19 \mathrm{~h}$.

(b) 1-2 August 1971 . the inland station; an example is shown in Fig. 9a. The wind directions are different day by day. Flow is offshore in the former but slmost parallel in the latter. The low level jet in the evening or nighttime has been discussed by several authors. It is well known that the occurrence of a low level jet is deeply connected with the existence of a nocturnal inversion layer near the ground surface. This is usually explained as speeding-up of the winds aloft owing to the decrease in the force of surface friction caused by the formation of a surface inversion layer (e.g., Blackadar, 1957; Barad, 1961). Simultaneous measurements of air temperature covering the entire layer were not made in 1971, only tower measurements up to 40 meters above the ground at JAERI are available. Table 1 shows the

Table 1. Temperatures at the JAERI meteorological tower

\begin{tabular}{c|c|c|c|c}
\hline Date & $\begin{array}{c}\text { Time of } \\
\text { day } \\
\text { (hr) }\end{array}$ & \multicolumn{2}{|c|}{$\begin{array}{c}\text { Temperature } \\
\left({ }^{\circ} \mathrm{C}\right)\end{array}$} & $\begin{array}{c}\text { Temp. } \\
\text { difference }\end{array}$ \\
\hline 30 July 1971 & 15 & 30.0 & 29.2 & -0.8 \\
& 16 & 28.7 & 27.8 & -0.9 \\
& 17 & 27.3 & 26.7 & -0.6 \\
& 18 & 27.9 & 28.1 & 0.2 \\
& 19 & 27.0 & 27.5 & 0.5 \\
& 20 & 27.1 & 27.3 & 0.2 \\
& 21 & 26.8 & 27.0 & 0.2 \\
\hline 1 August 1971 & 15 & 28.8 & 27.5 & -1.3 \\
& 16 & 28.0 & 27.0 & -1.0 \\
& 17 & 27.4 & 26.7 & -0.7 \\
& 18 & 26.0 & 25.6 & -0.4 \\
& 19 & 25.3 & 25.1 & -0.2 \\
& 20 & 25.3 & 25.3 & 0.0 \\
& 21 & 25.2 & 25.2 & 0.0 \\
\hline
\end{tabular}

temporal change of air temperature at 5 and 40 meters. On 30 July, a surface inversion layer appears after 1800 , while the air layer remains unstable or only slightly stable until 2100 on 1 August. Predominant depression at 1500 in Fig. 8 have almost disappeared and pressure gradient is considerably weakened at 2100 . This situation seems to correspond to lowering of the wind speed.

We proceed now to discuss the 1972 observations. Fig. 10 shows temporal change of winds aloft at the inland station on 28 to 29 July 1972. It is evident that wind directions shift offshore 


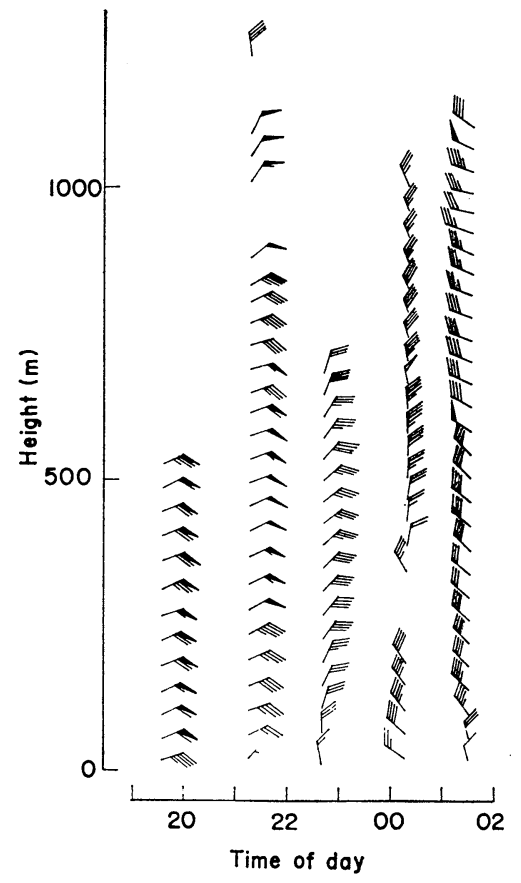

Fig. 10. Temporal change of winds aloft at the inland station (28-29, July, 1972). A barb indicates $1 \mathrm{~m} \cdot \mathrm{sec}^{-1}$, a half-barb $0.5 \mathrm{~m} \cdot \mathrm{sec}^{-1}$, and a pennant $5 \mathrm{~m} \cdot \mathrm{sec}^{-1}$.

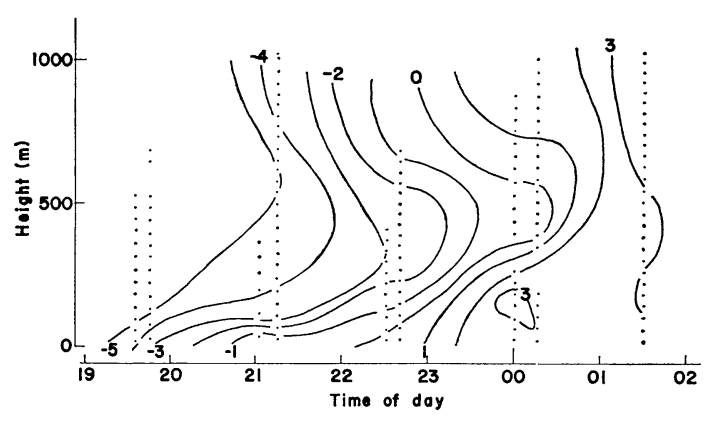

Fig. 11. Time cross-section of the wind speed component perpendicular to the coastline at the inland station (28-29 July 1972). Numerals show the values in meter per second, positive sign offshore.

from below. Allowing for some missing observations, the tendency is also recognizable at the coastal station (not shown). Time cross-section of a wind speed component perpendicular to the coastline is shown in Fig. 11. The development of the land breeze from the surface upwards is clearly seen. Similar directional change occurs simultaneously in the upper portion of the observed layer. The directional change in the upper portion is consistent with temporal change in flow pattern at $900 \mathrm{mb}$ level over the eastern part of Japan. It is evident that the directional change takes place in counter-clockwise sense, but it is clearly seen from Fig. 10 that the change is delayed in an atmospheric layer of about 400 meters height at 2240 and about 500 meters height at 0010. So it is unlikely that the change in the lower portion is due to synoptic cause. This sort of development can also be found out in the 1971 observations. Fig. 12 shows

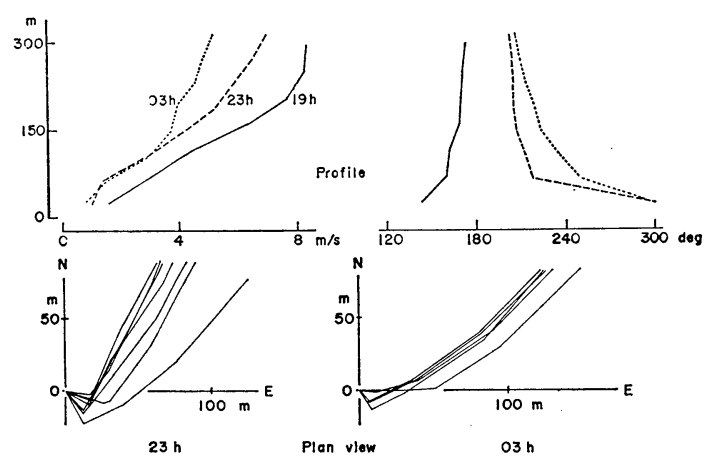

Fig. 12. Wind profiles and plan views of balloon trajectories in the offshore flow in the lower layer. The lower half shows individual trajectories of balloons at the respective time.

wind profiles and plan views of balloon trajectories around midnight of 1 to 2 August at the inland station. Wind directions in the lowest observed layer is WNW at 2300 and 0300 . A tendency is recognizable that the adjacent layer exhibits wind directions more perpendicular to the coastline in 0300 than in 2300. Steadiness of the flow in the lower layer is also shown in Fig. 12 by balloon trajectories for each ascent. This feature may suggest the development of the land breeze from the surface upwards with lapse of time, though the thermal condition is not so favorable for the generation of land breeze and the wind direction in the observed layer is mainly SW for the 1971 observations.

Corresponding feature for the sea breeze was obtained not in the 1972 but in the 1971 observations. Fig. 13 shows temporal change of winds aloft at the inland station on 31 July 1971. Wind directions shift offshore to onshore fairly simultaneously within the air layer below about 400 meters. Time cross-section of the wind 


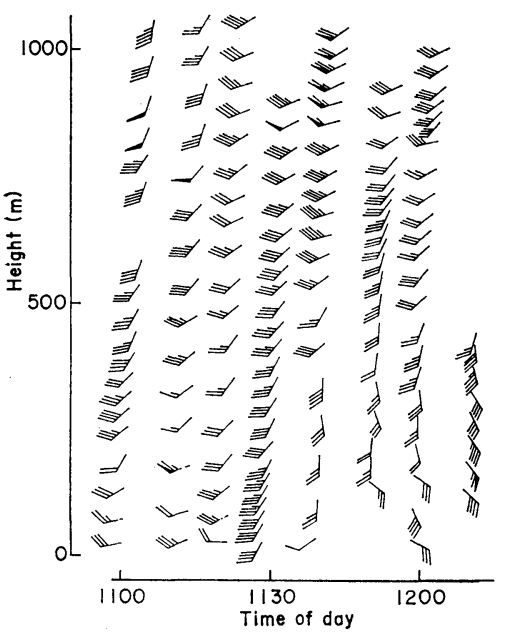

Fig. 13. Temporal change of winds aloft at the inland station $(11 \mathrm{~h}-12 \mathrm{~h}$, 31 July 1971). A barb indicates $1 \mathrm{~m} \cdot \mathrm{sec}^{-1}$, a half-barb $0.5 \mathrm{~m} \cdot \mathrm{sec}^{-1}$, and a pennant $5 \mathrm{~m} \cdot \mathrm{sec}^{-1}$.

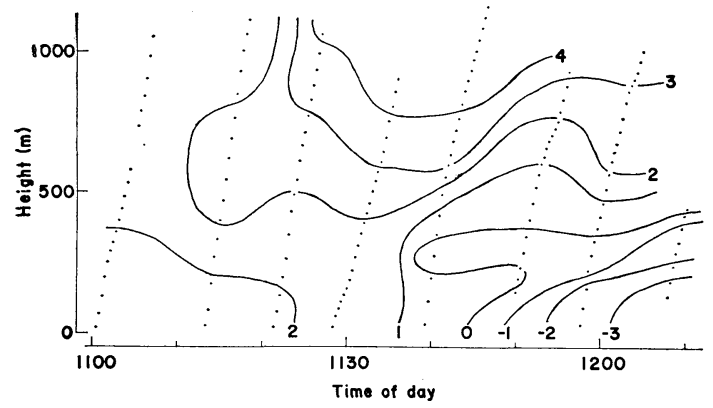

Fig. 14. Time cross-section of the wind speed component perpendicular to the coastline at the inland station $(11 \mathrm{~h}-12 \mathrm{~h}, 31$ July 1971). Numerals show the values in meter per second, negative sign onshore.

speed component perpendicular to the coastline is shown in Fig. 14. The feature described in Figs. 11 and 14 have also been obtained at Texas coast by Eddy (1966).

The structure of sea breeze front has been studied in detail by Berson (1958). The sea-breeze front observed in the present study is accompanied by rather sharp change in wind direction, speed and air temperature. Fig. 15a shows traces of wind direction, speed and air temperature for the case shown in Fig. 13. The velocity of the seabreeze front could be easily determined if there were one more such station available in the area. Another example is shown in Fig. 15b for 29

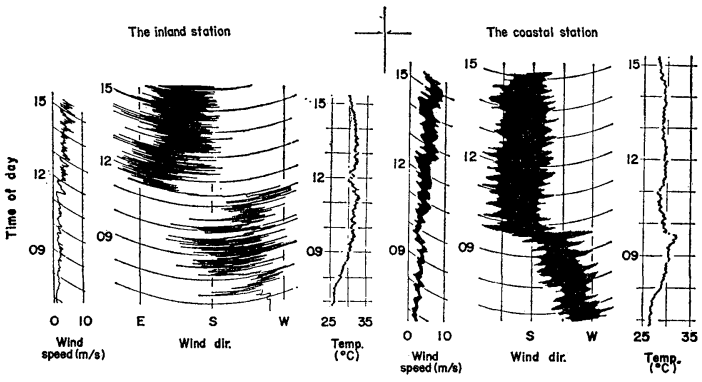

(a) 31 July 1971 .

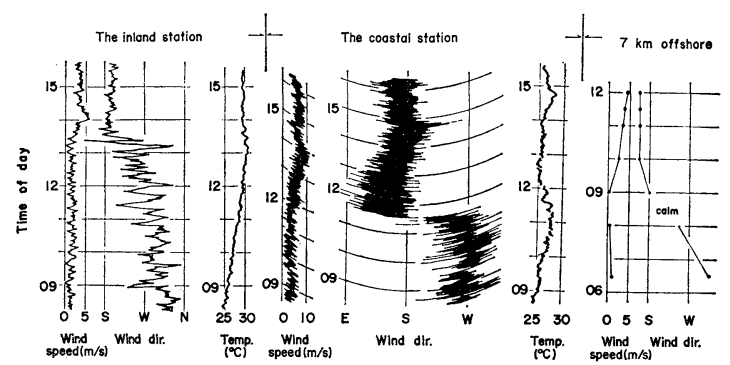

(b) 29 July 1972.

Fig. 15. Continuous records of wind and temperature during the change from land to sea breeze.

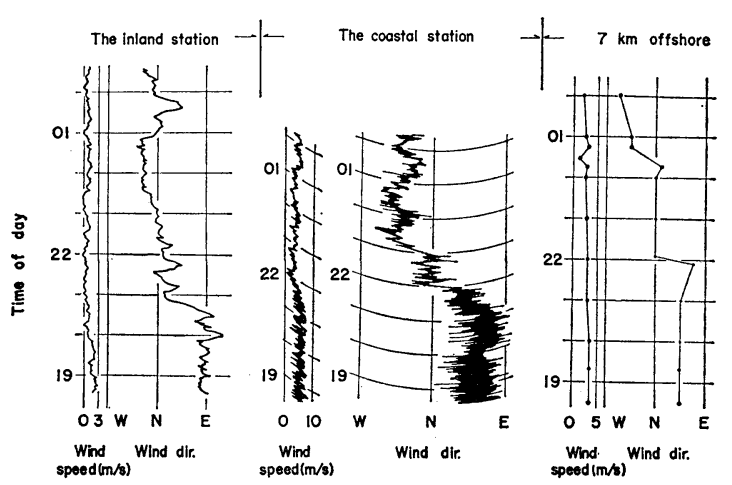

Fig. 16. Continuous records of wind during the change from sea to land breeze.

July 1972, which includes observations made on the vessel at about 7 kilometers off the coast. It is interesting that the wind turns onshore as early as 0900 at this point. The commencement of the land breeze observed in 1972 is rather gradual in nature. Somewhat abrupt changes are seen in continuous records of wind directions as is shown in Fig. 16 but not so sharp as in the case of the sea breeze. A significant feature shown here is that the wind shifts offshore at about 2300 over the land while it does not turn offshore till at about 0030 over the sea. No 
detectable change is seen in continuous records of air temperature (not shown).

Fig. 17 shows trajectories and heights of tetroon flights. The trajectories are shown to be fairly straight and there is no particular feature to be noted. Some vertical displacements exist in the daytime flights but such displacements are usual in the daytime. The tetroon released at the coastal station at 0430 was found at the seashore about
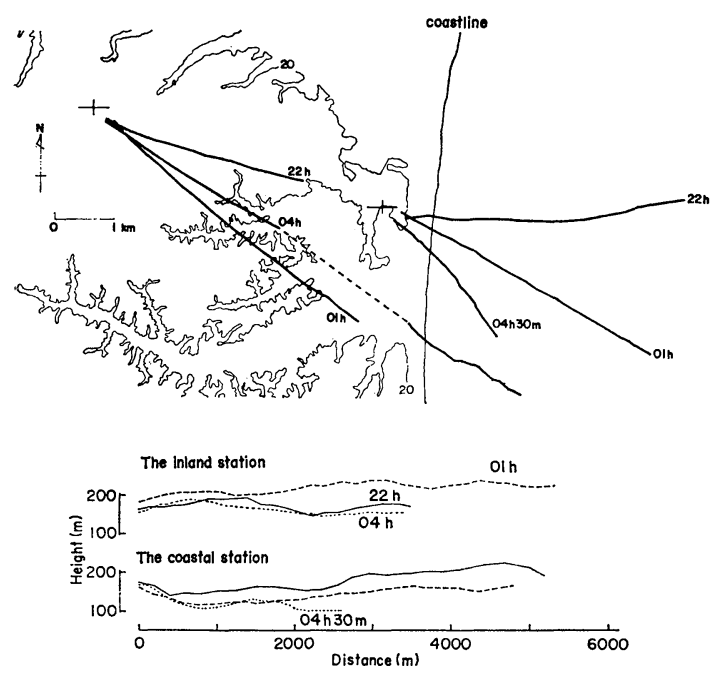

(a) Land breeze.
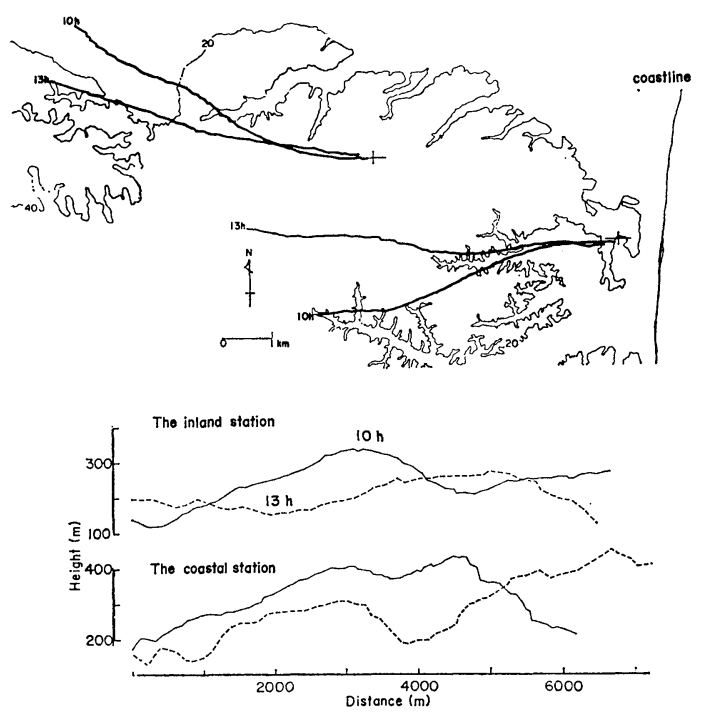

(b) Sea breeze.

Fig. 17. Trajectories and vertical displacement of tetroons. Numerals in the upper half show height above MSL. Distance in the lower half means that along the trajectory.
25 kilometers distant to the south in the afternoon of the same day, suggesting the existence of a closed circulation system of air flow.

\section{Conclusions}

In the summer of 1971 and 1972, observations on land and sea breezes were carried out by use of pibal method in the Tokai Village area whose topography is considered suitable for such observations. Two pibal stations were set up at about one and six kilometers inland from the coastline. For obtaining a representative wind profile by pibal observation, several balloons were released successively during an about one hour run and results were shown to be very satisfactory. This modification of pibal observation made sure of several interesting features on land and sea breeze.

Well-defined sea breezes were observed in the afternoon during the period when it was clear and wind appropriate to synoptic pressure gradient was weak. Vertical profiles of wind speed and direction in the lowest few hundred meters of the atmosphere are significantly different between the coastal and the inland station. Significant maximum in wind speed appears at about 100 meters above the ground surface at the coastal station but are almost absent at the inland station. Wind direction within a few hundred meters backed by 10 to 20 degrees from the coastline to the inland station. These features may suggest the effectiveness of the difference in surface friction over the land and the sea.

Wind directions observed in the sea breeze are rather parallel to the coastline. A predominant thermal low which is centered at a mountaineous region of central plateau district and covering the Kanto Plain in the daytime seems to affect largely the wind directions at the southeastern coast of Japan.

Low level jet in the evening was observed in the area. It is deeply connected with the existence of a surface inversion layer, consistent with wellknown account for low level jet. The jet looks diminishing as the thermal low disappears toward the midnight.

Time cross-sections of the wind speed component perpendicular to the coastline were obtained during the change from onshore to offshore flow and vice versa. The offshore flow develops from the surface upwards, suggesting a characteristic feature of land breeze under an opposing overriding flow. The wind directions shift simultaneously within 
the lowest 400 meters layer during the passage of the sea-breeze front at the inland station. Sharp discontinuities of cold front type are seen in continuous records of wind direction, speed and air temperature. The gradient flow at that time is too small to reinforce or oppose the sea breeze.

The observations of wind direction 7 kilometers offshore show a tendency for air flow to shift onshore prior to that over the land in the daytime and to shift offshore behind that over the land in the nighttime.

The investigations of air trajectories by use of tetroon with flight altitude of about 200 meters give an evidence of a closed circulation system of air flow in the vicinity of the coast. This phenomenon has considerable significance to environmental aspect of nuclear facilities. Detailed structure of the circulation is, however, left to further studies.

\section{Acknowledgements}

The authors are deeply indebted to Mitsubishi Nuclear Fuel Co. and Sumitomo Metal Mining Co. for observational sites and facilities, and to Meisei Electric Co. for radiosonde equipments. Mr. Jie-Chen Chen of Kansai Branch, Japan Meteorological Association kindly provided the authors with computing sheet and nomogram designed by him for the adjustment of tetroon. This paper was finished during one of the authors' (MM) stay in the Atmospheric Environment Service of Canada. They wish to express their gratitudes to Drs. G. A. McBean and H. C. Martin of the Service for their valuable advice. Finally they wish to express their sincere thanks to Mr. K. Imai and staff members of the JAERI Environmental Survey Section and Messrs. S. Iwamoto and H. Sano of Research Reactor Institute, Kyoto University for their constant encouragements and helpful assistance throughout the study.

\section{References}

Barad, M. L., 1961: Low altitude jet streams, Sci. Amer., 205, 120-131.

Berson, F. A., 1958: Some measurements on undercutting cold air, Quart. J. Roy. Met. Soc., 84, 1-16.

Blackadar, A. K., 1957: Boundary layer wind maxima and their significance for the growth of nocturnal inversions, Bull. Amer. Met. Soc., 38, 283-290.

Brooks, E. M., 1947: The accuracy and representativeness of the 10,000 -foot pibal report, Bull.
Amer. Met. Soc. 28, 405-408.

Davidson, B., 1963: Some turbulence and wind variability observations in the lee of mountain ridge, J. Appl. Met., 2, 463-472.

Eddy, A., 1966: The Texas coast sea-breeze: A pilot study, Weather, 21, 162-170.

Estoque, M. A., 1961: A theoretical investigation of the sea breeze, Quart. J. Roy. Met. Soc., 87, 136-146.

Fisher, E. L., 1960: An observational study of the sea breeze, J. Met. 17, 645-660.

Fraedrich, K., 1968: Das Land- und Seewindsystem des Victoria-Sees nach aerologischen Daten, Arch. f. Met. Geophys. u. Biokl., A, 17, 186-206.

Frizzola, J. A. and E. L. Fisher, 1963: A series of sea breeze observations in the New York City area, J. Appl. Met., 2, 722-739.

Hass, W. A., W. H. Hoecker, D. H. Pack and J. K. Angell, 1967: Analysis of low-level, constant volume balloon (tetroon) flights over New York City, Quart. J. Roy. Met. Soc., 93, 483-493.

Hsu, Shih-Ang, 1970: Coastal air-circulation system: Observations and empirical model, Mon. Wea. Rev., 98, 487-509.

Imai, K., 1968: Private communication.

Jehn, K. H., 1973: A sea breeze bibliography, 16641972, Report No. 37, Atmospheric Science Group, The University of Texas.

Johnson, A. Jr. and J. J. O'Brien, 1973: A study of an Oregon sea breeze events, J. Appl. Met., 12, 12671283.

Lyons, W. A., 1970: Mesoscale transport of pollutants in the Chicago area as affected by land and lake breezes, Paper presented at 2nd Internat'l Clean Air Congr., Washington, D. C., Dec. 1970.

Magata, M., 1965: A study of the sea breeze by the numerical experiment, Pap. Met. Geophys., 16, 23-37.

McPherson, R. D., 1970: A numerical study of the effect of a coastal irregularity on the sea breeze, J. Appl. Met., 9, 767-777.

Mizuma, M., 1973: Small wind-shear layer observed at Research Reactor Institute, Kyoto University, J. Met. Soc. Japan, II, 51, 367-371.

Moroz, W. J., 1967: A lake breeze on the eastern shore of Lake Michigan: Observations and model, J. Atmos. Sci., 24, 337-355.

Neumann, J. and Y. Mahrer, 1971: A theoretical study of the land and sea breeze circulation, J. Atmos. Sci., 28, 532-542.

Yoshikado, H. and T. Asai, 1972: A numerical experiment of effects of turbulent transfer processes on the land sea breeze, Contr. Geophys Inst.,Kyoto. Univ., 12, 33-48.

Wexler, R., 1946: Theory and observations of land and sea breezes, Bull. Amer. Met. Soc., 27, 272-287. 


\title{
東海村における海陸風の観測的研究
}

\author{
水 間 満 郎 \\ 京都大学原子炬実験所
}

角田道生

日本原子力研究所

1971 および 72 年の夏期, 茨城県東海村においてパイバル観測を主とする一連の海陸風観測がおこなわれた。 パイ バル観測点は海岸より $1 \mathrm{~km}$ および $6 \mathrm{~km}$ に 2 個所設置された.

得られた主な結果は次の通りである.

（1）海風について, 地上数百米の気層内での風向風速の鉛直分布は, 海岸点と内陸点とで顕著な差異を示し, 地 面の摩擦応力と海面のそれとの差異の効果を示唆する.

（2）夕刻における低層ジェットはこの地域でる観測され, その発達と接地逆転層の存在との間に関連がみられた.

（3）観測された海風は明瞭な海風前線を伴い，海風の厚さは前線の付近で約 $400 \mathrm{~m}$ である. 観測された陸風は, 上層に海から吹く風が存在するとき，下層から徐々に発達するのがみられた。

観測船による海上での風向風速および気温海水温の観測, およびテトルーンを使用した流跡線の観測も計画の一環 としておこなわれた. 